DOI: 10.32999/2663-970X/2020-4-6

Link article (Style APA): Shevchenko N. F. \& Shevchenko A. I. (2020). Research of features of the mercy manifestation of doctors. Insight: the psychological dimensions of society, 4, 90-110. DOI: $10.32999 / 2663-970 X / 2020-4-6$

Link article (Style DSTU 8302: 2015): Shevchenko, N. F. \& Shevchenko, A. I. Research of features of the mercy manifestation of doctors. Insight: the psychological dimensions of society, 2020, 4, 90-110. DOI: $10.32999 / 2663-970 X / 2020-4-6$

UDC 159.98:614.253:177.72

\title{
Research of features of the mercy manifestation of doctors
}

\author{
Дослідження особливостей прояву милосердя у лікарів
}

Received: June 13, 2020 Accepted: October 30, 2020

\author{
Shevchenko Nataliia Fedorivna \\ Doctor of Psychological Sciences, Professor \\ Department of Pedagogy and Psychology \\ Zaporizhzhia national university, \\ Ukraine \\ ShevchenkoNF.20@gmail.com, \\ ORCID 0000-0002-5297-6588 \\ Shevchenko Anatolii Ivanovich \\ $\mathrm{PhD}$ in Medicine, Professor \\ Department of Oncology and Oncosurgery \\ Zaporizhzhia state medical university, \\ Ukraine \\ shevchenkoai.49@gmail.com, \\ ORCID 0000-0001-8553-1203
}

\author{
Шевченко Наталія Федорівна \\ доктор психологічних наук, професор \\ кафедра педагогіки та психології \\ Запорізький національний університет, \\ Україна \\ ShevchenkoNF.20@gmail.com, \\ ORCID 0000-0002-5297-6588 \\ Шевченко Анатолій Іванович \\ доктор медичних наук, професор \\ кафедра онкології та онкохірургії \\ Запорізький державний медичний \\ університет, Україна \\ shevchenkoai.49@gmail.com, \\ ORCID 0000-0001-8553-1203
}

\begin{abstract}
The purpose of the article is to highlight results of an empirical research of features of the mercy manifestation of doctors.

The research methods include theoretical: induction and deduction, analysis, synthesis, generalization; empirical: "Sacks sentence completion test" (by J. Sachs, in modification), "Diagnosis of empathic abilities" (by V. Boyko), "Empathic potential of an individual" (by I. Yusupov), "Diagnosis of social and psychological attitudes of an individual in the motivational sphere" (by 0. Potiomkina); mathematical and statistical methods. Results. The research of manifestation of the mercy of the medical staff has shown that most of the studied parameters are in the range of the average level.
\end{abstract}

\begin{abstract}
Анотація
Мета. Метою статті $є$ висвітлення результатів емпіричного дослідження особливостей проявів милосердя в лікарів. Методи. Для реалізації поставленої мети використано теоретичні: індукції і дедукції, аналізування, синтезування, узагальнення та емпіричні методи дослідження: “Методика незакінчених речень” (Дж. М. Сакс, модиф.), “Діагностика емпатійнихздібностей” (В. В. Бойко), “Емпатійний потенціал особистості” (I. М. Юсупов), “Діагностика соціально-психологічних настанов особистості в мотиваційно-потребовій сфері” (О. Ф. Потьомкіна); математико-статистичні методи. Результати. Дослідження прояву милосердя у лікарів засвідчило, що більшість досліджуваних параметрів зафіксовано в діапазоні середнього рівня. Вивчення прояву когнітивного компонента показало, що для
\end{abstract}

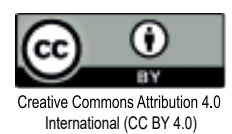


Study of the cognitive component manifestation has shown that respondents can be characterized by a positive perception of help and charity, by a lower attitude to empathy. Study of the empathic abilities (emotional-and-motivational component) has shown that the doctors tend to rely on a rational channel of empathy, have well-developed guidelines for empathy and prefer to create a trusting atmosphere. Research of personal social and psychological sets in the motivational and needs sphere (emotional-and-motivational component) has recorded an average level of altruistic orientations. Study of manifestation of the behavioral component of mercy has indicated that the medical staff mainly shows empathy towards parents, towards the elderly and towards strangers or unfamiliar people. The average level of empathy in behavior has been stated. Conclusions. The study has confirmed the assumption that the mercy as an integral personally and professionally significant quality of a medical worker is determined by the harmonious development of cognitive, emotional-and-motivational and behavioral components, and it is not manifested enough in usual conditions of professional activity.

Keywords: mercy, mercy of medical workers, altruism, empathy, orientation, compassion.

\section{Introduction}

Relevance of study of the mercy is caused by the current state of Ukrainian society, which exists at the stage of values revision and requires active participation in the formation of new moral and ethical concepts. Political and economic transformations, dramatic events of the recent years show an urgent need for reference points that should be of particular importance in this difficult period.

These questions have to be answered by modern psychology and must not focus only on the study of the personal values sphere, but on the contrary, should actively explore and offer different versions of life senses and values. It is necessary to highlight the mercy phenomenon for its entry into the categorical system of psychology as a condition for revaluation of the old and creation of the new values.

There is an urgent need to define the concept of the "mercy" and to separate it from synonymous concepts ("compassion", "ability to forgive", "charity", etc.). It is important to analyze its досліджуваних характерним є позитивне сприйняття допомоги та позитивне уявлення про милосердя, водночас уявлення про емпатію виявилися нижчими. Вивчення емпатійних здібностей (емоційно-мотиваційний компонент) засвідчило, що лікарі схильні спиратися на раціональний канал емпатії, мають розвинені настанови на емпатію та надають перевагу створенню довірливої атмосфери. Дослідження соціально-психологічних настанов особистості у мотиваційно-потребовій сфері (емоційно-мотиваційний компонент) зафіксували середній рівень прояву альтруїстичних настанов. Вивчення прояву поведінкового компонента милосердя показало, що для лікарів найбільш характерно проявляти емпатію по відношенню до батьків, по відношенню до людей похилого віку та по відношенню до незнайомих або малознайомих людей. Констатовано середній рівень прояву емпатії у поведінці. Висновки. В ході дослідження підтверджено припущення про те, що милосердя як інтегральна особистісно і професійно значуща якість лікаря, визначається гармонійним розвитком когнітивного, емоційно-мотиваційного та поведінкового компонентів, і в звичайних умовах професійної діяльності проявляється недостатньо.

Ключові слова: милосердя, милосердя лікарів, альтруїзм, емпатія, спрямованість, співчуття.

\section{Вступ}

Актуальність вивчення милосердя обумовлена сучасним станом українського суспільства, яке знаходиться на стадії перегляду цінностей та потребує активної участі в формуванні нових морально-етичних концепцій. Політичні та економічні перетворення, драматичні події останніх років показують нагальну потребу у відповідях на питання щодо того, які орієнтири мають набути особливого значення у цей непростий період.

Саме на ці питання повинна відповідати сучасна психологія і не зосереджуватися лише на вивченні ціннісної сфери особистості, а навпаки, має активно досліджувати та пропонувати різні варіанти життєвих смислів та цінностей. Виділення феномену милосердя $\epsilon$ необхідним для його входження до категоріальної системи психології як умови для переоцінки старих та створення нових цінностей.

Існує нагальна необхідність у визначенні поняття “милосердя" та відокремлення його від синонімічних понять (“співчуття", 
structure, levels of development and opportunities for purposeful development of human ability to manifest the mercy. One of the ways of consideration of this construct should be studying the prospects of upbringing the mercy by psychological practice and its connection with improving the quality of life.

Mercy in the structure of doctors' personality attracts special attention as doctors are bearers of humanistic principles acting in modern Ukraine. According to provisions of the Code of Ethics for doctors in Ukraine, based on the principles of humanism and mercy, the main values are human life and health, and the doctor must adhere to certain moral principles. Among them are humane attitude to people, compassion and complicity, benevolence, charity and mercy, patience, mutual trust, decency and justice.

The mercy phenomenon has been disseminated in various studies and presented by the concepts of mercy by domestic and foreign psychologists and educators. Ukrainian scientists have studied peculiarities of the mercy manifestation of doctors and representatives of other professions (Shevchenko \& Markova, 2019), formation of professionally significant qualities of future nursing specialists (Danyuk, 2016), the influence of the motivational sphere on the cognitive activity and professional development of future doctors (Borysiuk, 2019), the act of mercy as the moral formation of a personality (Koval, 2017), psychological features of the empathy formation of future doctors (Yudina, 2004). Foreign scientists have studied the education of mercy of future nurses (Nedovodieeva, 2006), development of the compassion (Gilbert, 2019), phenomenon of the forgiveness (Luskin, 2010), empathy (Gelhaus, 2012) and self-compassion (Neff \& Germer, 2017).

Analysis of domestic and foreign literature has shown that, despite the presentation of a large number of theoretical studies which offer different views on the essence of the mercy, there is a shortage of empirical research on mercy as an independent phenomenon, in the context of professional qualities. Particularly, research of the mercy manifestation of representatives of the medical sphere is insufficiently presented. Research of features of this phenomenon will “здатність до пробачення", “доброчинність” тощо). Важливо здійснити аналіз його структури, рівнів розвитку та можливостей цілеспрямованого розвитку здатності людини виявляти милосердя. Одним з напрямків розгляду цього конструкту має стати вивчення перспектив виховання милосердя засобами психологічної практики та його зв'язку з покращенням якості життя.

Особливу увагу привертає милосердя в структурі особистості лікарів як носіїв гуманістичних засад, що діють у сучасній Україні. Виходячи з положень Етичного кодексу лікаря України, заснованого на принципах гуманізму та милосердя, основними цінностями наголошуються життя та здоров'я людини, а лікар має дотримуватись певних моральних принципів. Серед них - гуманне ставлення до людини, співчуття та співучасть, доброзичливість, благодійність та милосердя, терплячість, взаємодовіра, порядність та справедливість.

Феномен милосердя висвітлювався у різноманітних дослідженнях та представлений концепціями милосердя вітчизняних і зарубіжних психологів та педагогів. Вітчизняними науковцям вивчалися особливості прояву милосердя у лікарів та представників інших професій (Shevchenko, Markova, 2019), формування професійно значущих якостей майбутніх молодших спеціалістів сестринської справи (Данюк, 2016), вплив мотиваційної сфери на пізнавальну активність та професійне становлення майбутніх лікарів (Borysiuk, 2019), вчинок милосердя як моральне становлення особистості (Коваль, 2017), психологічні особливості формування емпатійності майбутніх лікарів (Юдіна, 2004). Зарубіжними науковцями досліджено виховання милосердя у майбутніх медичних сестер (Недоводеева, 2006), розвиток співчуття (Gilbert, 2019), феномен прощення (Luskin, 2010), емпатії (Gelhaus, 2012) та само-співчуття (Neff, Germer, 2017).

Аналіз вітчизняної та зарубіжної літератури показав, що, незважаючи на представленість великої кількості теоретичних досліджень, які пропонують різні погляди на сутність милосердя, існує дефіцит емпіричних досліджень милосердя як самостійного феномену, в контексті професійних якостей. Зокрема, недостатньо

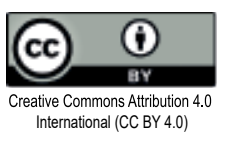


allow developing practical measures of increasing the level of doctors'mercy.

Hypothesis. The study has been based on the assumption that the mercy as an integral personally and professionally significant quality of a doctor is determined by the harmonious development of cognitive, emotional-andmotivational and behavioral components; under usual conditions of profession alactivity, mercy is not manifested enough.

The purpose of the research is to highlight the results of an empirical study of the mercy manifestation of doctors.

\section{Methodology}

In the study, we relied on scientific developments on the criteria for the mercy formation (Nedovodieeva, 2006), formation of the professionally significant qualities of the medical stuff and future doctors (Borysiuk, 2019; Danyuk, 2016; Halian et al., 2020; Matiukha et al., 2020; Mitina, 2017; Solodukho, 2014; Yudina, 2004; Yuriyeva, 2019), development of compassion (Gilbert, 2019; Neff \& Germer, 2017).

Research methods: theoretical: induction and deduction (for formation and testing of the hypothesis), analysis, synthesis, generalization (analysis and synthesis of literature on the selected problem, synthesis and generalization of the results); empirical: psychodiagnostic methods for studying a structure of the mercy, degree of development of the mercy components, psychological characteristics of an individual; mathematical and statistical methods.

\section{Research sample}

The research sample consisted of 120 doctors working in Zaporizhia Regional Oncology Dispensary, "Oncolife" Medical Center and Zaporizhia Emergency and Ambulance Hospital. Age of respondents 25-45 years, professional experience is 5-17 years.

\section{Procedures and instruments}

Empirical study of the mercy manifestation of doctors has been held in 2019-2020 in three stages.

The first stage is an implementation of theoretical analysis of psychological and pedagogical literature on the research topic, determination of approaches to the study of the problem, substantiation of the structural model of doctors' mercy. представлені дослідження прояву милосердя у представників медичної сфери. Вивчення особливостей цього феномену дозволить розробити практичні заходи з підвищення рівня прояву милосердя у лікарів.

Гіпотеза. В основу дослідження було покладено припущення про те, що милосердя, як інтегральна особистісно і професійно значуща якість лікаря, визначається гармонійним розвитком когнітивного, емоційно-мотиваційного та поведінкового компонентів і в звичайних умовах професійної діяльності проявляється недостатньо.

Мета дослідження - висвітлення результатів емпіричного дослідження особливостей прояву милосердя у лікарів.

\section{Методологія}

В дослідженні ми спиралися на наукові розробки щодо критеріїв сформованості милосердя (Недоводеева, 2006), формування професійно значущих якостей медичних працівників, та майбутніх лікарів (Borysiuk, 2019; Halian et al., 2020; Данюк, 2016; Мітіна, 2017; Солодухо, 2014; Юдіна, 2004; Yuriyeva, 2019), розвитку співчуття (Gilbert, 2019; Neff, Germer, 2017).

Теоретичні методи дослідження: індукції і дедукції (для формування та перевірки гіпотези), аналізування, синтезування, узагальнення (аналізування і синтезування літератури з обраної проблеми, синтезування і узагальнення отриманих результатів). Емпіричні: психодіагностичні методики для дослідження структури милосердя, ступеню розвитку складових милосердя, психологічних особливостей особистості; математико-статистичні методи.

\section{Учасники}

Дослідницьку вибірку склали 120 лікарів. Вік досліджуваних 25-45 років, професійний стаж 5-17 років. Респондентами виступили лікарі Запорізького обласного онкологічного диспансеру, МЦ “Онколайф” та Міської лікарні екстреної та швидкої медичної допомоги м. Запоріжжя.

Процедура та інструменти

Емпіричне вивчення особливостей прояву милосердя у лікарів проводилося в 2019-2020 роках у три етапи. 
The second stage is a selection of a reliable package of diagnostic techniques, formation of a research sample, conduction of an empirical study of the mercy manifestation of doctors.

The third stage is quantitative processing and qualitative analysis of the received data, interpretation of the results, analysis of methods of increasing the level of the mercy manifestation of doctors.

Psychodiagnostic tools consisted of the following methods: "Sacks sentence completion test" (author J. Sachs, in modif.) to study an individual attitude to the help, idea of the mercy, general empathic abilities; "Diagnosis of empathic abilities" (V. Boyko) in order to study manifestations of the empathy as an individual ability to empathize with problems of others; "Empathic potential of a personality" (I. Yusupov) to research the emotional individual response to the experiences of others; "Diagnosis of social and psychological attitude of an individual in the motivational and needs sphere" (0. Potiomkina) in order to study social and psychological sets of an individual.

\section{Data analysis}

Mathematical and statistical methods of experimental data processing based on the IBM SPSS-20 statistical software package: quantitative and qualitative analysis of the research results, descriptive statistics (calculation of average values, finding the percentage distribution), correlation method by K. Pearson.

\section{Results}

A doctor's constant interactions with a patient, which provide care and render necessary assistance, are an important condition for recovery and suggest a fairly high level of professionally significant moral and cultural qualities. Namely: mercy (humanity, empathy, sensitivity, benevolence), attentiveness, sincerity, honesty, optimism, emotional restraint, patience, compassion, care, politeness, tact, sociability, tolerance. The main psychological factor in its development is the desire to help patients, promoting their treatment and getting rid of physical and mental illnesses (Ushakova, 2018).

The mercy, from the point of view of the medical ethics and deontology, should be a foundation on which a doctor's professional development
Перший етап: здійснення теоретичного аналізу психолого-педагогічної літератури 3 теми дослідження, визначення підходів до вивчення проблеми, обгрунтування структурної моделі милосердя лікарів.

Другий етап: здійснення підбору надійного пакету діагностичних методик, формування дослідницької вибірки, проведення емпіричного дослідження особливостей прояву милосердя лікарів.

Третій етап: кількісна обробка і якісний аналіз отриманих даних, здійснення інтерпретації результатів дослідження, аналіз методів підвищення рівня прояву милосердя у лікарів.

Психодіагностичний інструментарій склали такі методики: "Методика незакінчених речень" (Дж. М. Сакс, модиф.) - для дослідження ставлення особистості до допомоги, уявлення про милосердя, загальних емпатійних здібностей; “Діагностика емпатійних здібностей” (В. В. Бойко) - 3 метою дослідження проявів емпатії як здатності особистості співпереживати проблемам інших людей; “Емпатійний потенціал особистості” (I. М. Юсупов) - для вивчення емоційного відгуку особистості на переживання інших; "Діагностика соціально-психологічних настанов особистості у мотиваційно-потребовій сфері" (О. Ф. Потьомкіна) з метою дослідження соціально-психологічних настановлень особистості.

\section{Статистичне аналізування}

Математико-статистичні методи обробки експериментальних даних здійснювалося на базі пакету статистичних програм IBM SPSS v. 20: кількісний і якісний аналіз результатів дослідження, описова статистика (обчислення середніх значень, знаходження процентного розподілу), метод кореляції за К. Пірсоном.

\section{Результати}

Постійні взаємодії лікаря з пацієнтом, які передбачають догляд і надання останньому необхідної допомоги та $\epsilon$ важливою умовою одужання, передбачають досить високу розвиненість низки професійно-значущих моральних і культурних якостей. А саме: милосердя (гуманності, емпатійності, чуйності, доброзичливості), уважності, щирості, чесності, оптимізму, емоційної стриманості, терплячості, 
and patients' care is based. It is a supporting factor in the development of the ability and desire to professional caring and compassion. The mercy can be both method and purpose, and result of the professional education. A doctor's mercy is closely linked to empathy, which is a professionally important quality.

Based on a theoretical analysis of the mercy problem (Nedovodieeva, 2006) and taking into consideration specifics of the medical activities (Ushakova, 2018), we have elaborated a structural model of doctors' mercy, which includes cognitive, emotional-and-motivational and behavioral components (Fig. 1). The cognitive component includes notions of the mercy, awareness of need for the mercy behavior. Emotional-andmotivational component is characterized by the developed status of the empathic abilities, personal social and psychological orientation for altruism. The behavioral component is manifested in implementation of the certain mercy behavior.

With purpose of the complex quantitative and qualitative analysis of results of the research, the received data will be presented according to the structural and semantic essence of the mercy manifestation of doctors.

In order to learn the awareness of need for the mercy behavior and attitudes towards the mercy in general we used Sacks sentence completion test. According to the obtained data, the respondents have not reached the maximum value on the scales ( 8 points), the results quickly reach the average values (attitude to help - 2.87 points; notions of the mercy3.91 points; notions of the empathy - 1.4 points). It is also possible to note the absence of sharply negative tendencies in the group - on average, the attitude to these three key parameters is mainly positive.

The respondents can be characterized by a positive attitude to help (in relation to both help as sister and recipient of help) and a positive perception of the mercy, while notions of the empathy have lower scores. According to the obtained data, doctors tend to perceive their care as something free, without expecting a reward; they think that the help to another person should not burden them. The respondents are positively attuned to situations співчутливості, турботливості, ввічливості, тактовності, комунікабельності, толерантності. Основний психологічний чинник їх розвитку - це прагнення допомагати пацієнтам, сприяючи їх лікуванню та позбавляючи від фізичних і психічних хвороб (Ушакова, 2018).

Милосердя, 3 точки зору медичної етики та деонтології, має бути фундаментом, на якому грунтується професійний розвиток лікаря та догляд за хворими. Воно є допоміжним фактором у розвитку вміння та бажання професіонально проявити турботу і співчуття. Милосердя може виступати і засобом, і метою, і результатом професійної підготовки. Милосердя лікаря розглядається у тісному зв'язку з емпатією, що $€$ його професійно важливою якістю.

На підставі теоретичного аналізу проблеми милосердя (Недоводеева, 2006) та беручи до уваги специфіку медичної діяльності (Ушакова, 2018), нами розроблена структурна модель милосердя лікарів, яка включає когнітивний, емоційно-мотиваційний та поведінковий компоненти (рис. 1). Когнітивний компонент включає уявлення про милосердя, усвідомлення необхідності милосердної поведінки. Емоційно-мотиваційний компонент характеризується розвиненістю здібностей до емпатії, соціально-психологічна настанова особистості на альтруїзм. Діяльнісний компонент виявляється у реалізації певної милосердної поведінки.

3 метою комплексного кількісного та якісного аналізу результатів дослідження особливостей прояву милосердя у лікарів, отримані дані будуть подані відповідно до структурно-змістової сутності милосердя.

Для вивчення усвідомлення необхідності милосердної поведінки та ставлення до милосердя взагалі ми використовували методику незакінчених речень. Згідно з отриманими даними, досліджувані не досягли максимального значення за шкалами (8 балів), результати швидше добирають середніх значень (ставлення до допомоги - 2.87 балів; уявлення про милосердя - 3.91 балів; уявлення про емпатію 1.4 балів). Можна також відмітити відсутність різко негативних тенденцій у групі - в середньому, ставлення до цих трьох ключових параметрів $\epsilon$ більшою мірою позитивним.

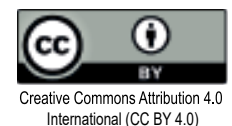




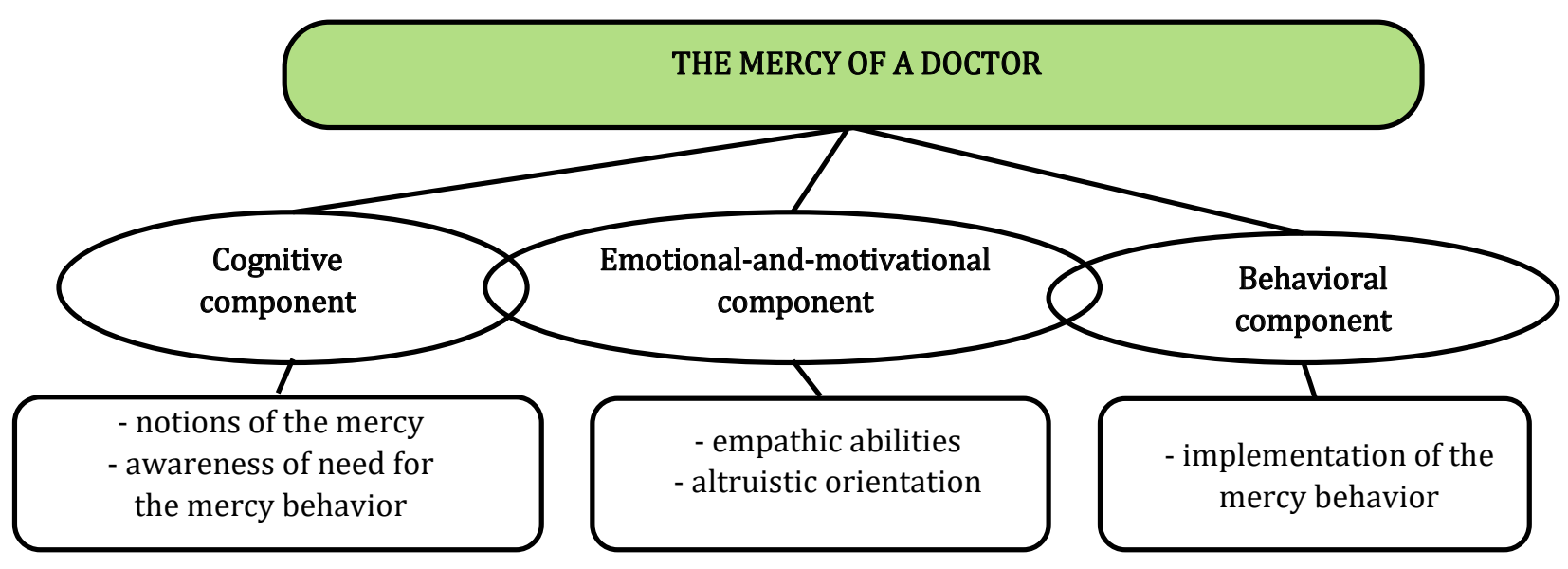

Fig. 1. Structural model of the mercy of a doctor

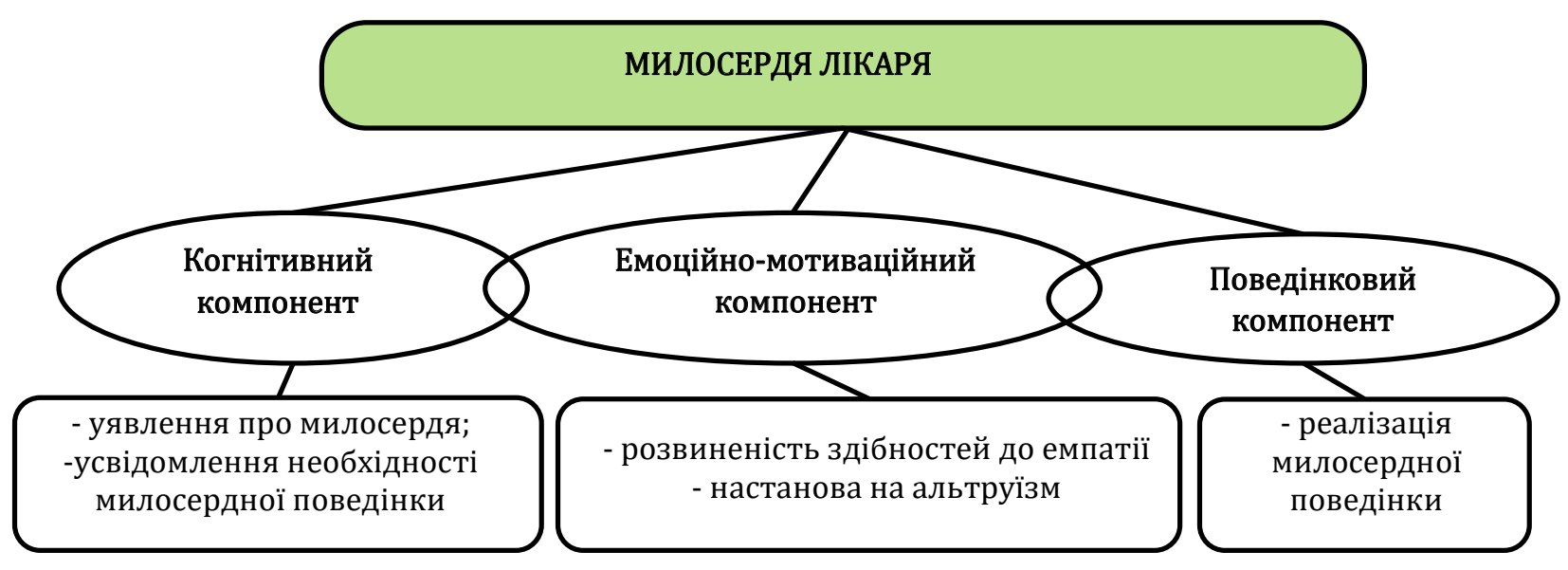

Рис. 1. Структурна модель милосердя лікаря

in which there is either provision or receipt of assistance from another person. For a doctor, help is not a "special" way of acting and does not carry additional values, but rather is aimed at solving a difficult situation.

Here are examples of the most representative statements. The most positive attitude to the mercy can be illustrated by the following sentences: "The gift of good people"; "Helping others fills you"; "This is great".

A sharply negative attitude to the mercy may be expressed, in our opinion, by the following notions: "You can be used"; "This is a weakness"; "Something bad is happening".

The most positive attitude to help and willingness to help can be illustrated by the
Для досліджуваних характерним $є$ позитивне сприйняття допомоги (у відношенні як до об'єкта, що отримує допомогу, так і до суб'єкта, що сприймає іï) та позитивне уявлення про милосердя, водночас показники уявлень про емпатію виявилися нижчими. Згідно з отриманими даними, лікарі схильні сприймати свою допомогу як щось безоплатне, без очікування винагороди; вони не вважають, що допомога іншій людині має їх обтяжувати. Досліджувані позитивно налаштовані на ситуації, у яких фігурує або надання, або отримання допомоги з боку іншої людини. Для лікаря допомога не є “особливим" способом дій та не несе додаткових значень, а скоріше спрямована на вирішення складної ситуації. 
following statements: "I do my best"; "I get a lot of pleasure"; "I feel my own significance".

A sharply negative attitude to help: "It leads to impudence of people"; "I have problems"; "It's not real".

To the most positive attitude to empathy, we included the following statements: "I try to help, cheer up"; "It makes me better"; "I'm upset if someone is upset".

Sharply negative perception of empathy: "The heart cannot stand"; "It will end badly for me"; "I will go crazy" and so on.

Interestingly, although the views of the majority of respondents match up on the condition of receiving help - namely, in order to receive help, one only needs to ask for it, they also perceive it as something that can appear as an object of exchange. That is, there is a contradiction between the mind attitudes "to get help, you just have to ask" and "when they help me, they always expect rewards".

Consider specifics of the empathic abilities of doctors. Results obtained by the method of V. Boyko are presented in Fig. 2.

The received data have shown that the studied doctors tend to rely on a rational channel of empathy (2.95 points), have developed mind attitudes for empathy (3.37 points) and prefer to create a trusting atmosphere (3.3 points). The respondents have also shown average scores of the ability to identify (2.8 points), that is the basis of empathy. At the same time, respondents rely less on the emotional channel of empathy (2.6 points), which is understood as entering into emotional resonance with another, deep compassion and complicity. This channel of empathy is also associated with a certain energy adjustment in order to understand the inner world and behavior of an interlocutor. As a result, doctors use the emotional channel of empathy less: they are not willing to expend mental energy to establish an emotional connection or deepen into the inner psychological life of a person. Slightly higher indicators on the scale of the intuitive channel of empathy (2.7 points) indicate the willingness of the respondents to rely primarily on illogical and subconscious knowledge in assessing behavior and condition of a partner.
Наведемо приклади найбільш характерних висловлювань. Максимально позитивне ставлення до милосердя можна проілюструвати такими продовженнями речень: "дар добрих людей”; “допомога іншим тебе наповнює”; "це чудово".

Різко негативне ставлення до милосердя виражається, на нашу думку, такими уявленнями: "тобою можуть скористатися"; “це слабкість”; “трапляється щось погане”.

Максимально позитивне ставлення до допомоги та готовність допомагати можна проілюструвати такими висловлюваннями: "роблю все можливе”; “отримую сильне задоволення”; "відчуваю власну значущість”.

Різко негативне ставлення до допомоги: “призводить до зухвалості людей"; “у мене виникають проблеми"; “це несправжність”.

До максимально позитивного ставлення до емпатії ми віднесли такі висловлювання: “намагаюсь допомогти, розвеселити”; “це робить мене краще”; “засмучуюсь, якщо хтось засмучений".

Різко негативне сприйняття емпатії: "серце не витримає”; “погано для мене закінчиться"; "зійду з розуму" тощо.

Цікаво, що, хоча погляди на умову отримання допомоги більшості досліджуваних збігається - а саме, для того, щоб отримати допомогу, необхідно лише попрохати про неї, вони також сприймають ії як щось, що може фігурувати як предмет обміну. Тобто, існує протиріччя між настановами “щоб отримати допомогу, треба лише попрохати" та "коли мені допомагають, завжди очікують винагороди".

Розглянемо специфіку емпатійних здібностей лікарів. Результати, отримані за методикою В. В. Бойка, представлені на рис. 2.

Отримані дані засвідчили, що досліджувані лікарі схильні спиратися на раціональний канал емпатії (2.95 балів), мають розвинені настанови на емпатію (3.37 балів) та надають перевагу створенню довірливої атмосфери (3.3 балів). Також досліджувані отримали середні показники здатності до ідентифікації (2.8 балів) - що, як показано у теоретичній частині роботи, є основою емпатії. Водночас, респонденти меншою мірою спираються на емоційний канал емпатії (2.6 балів), що 


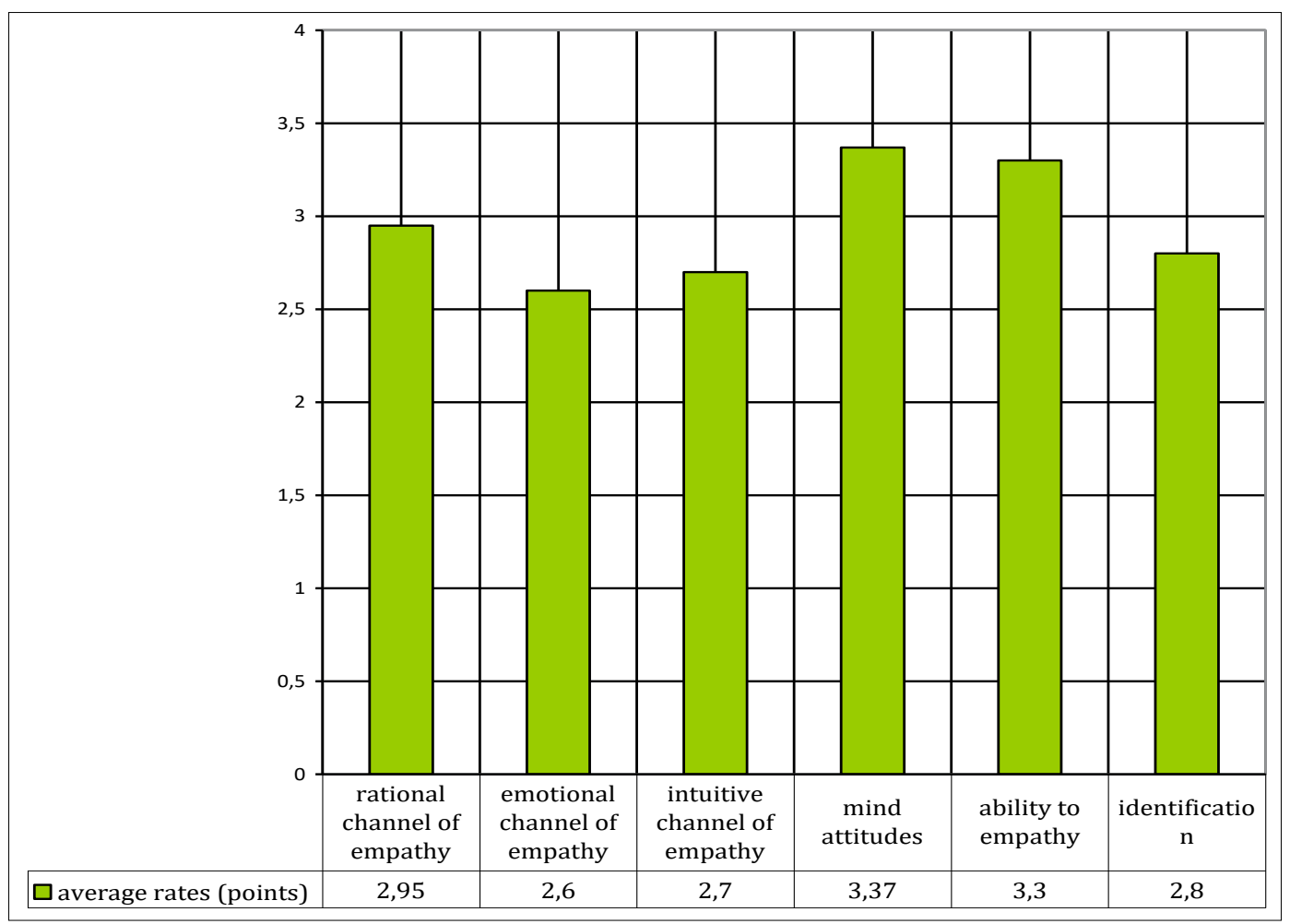

Fig. 2. Indicators of the empathic abilities of doctors

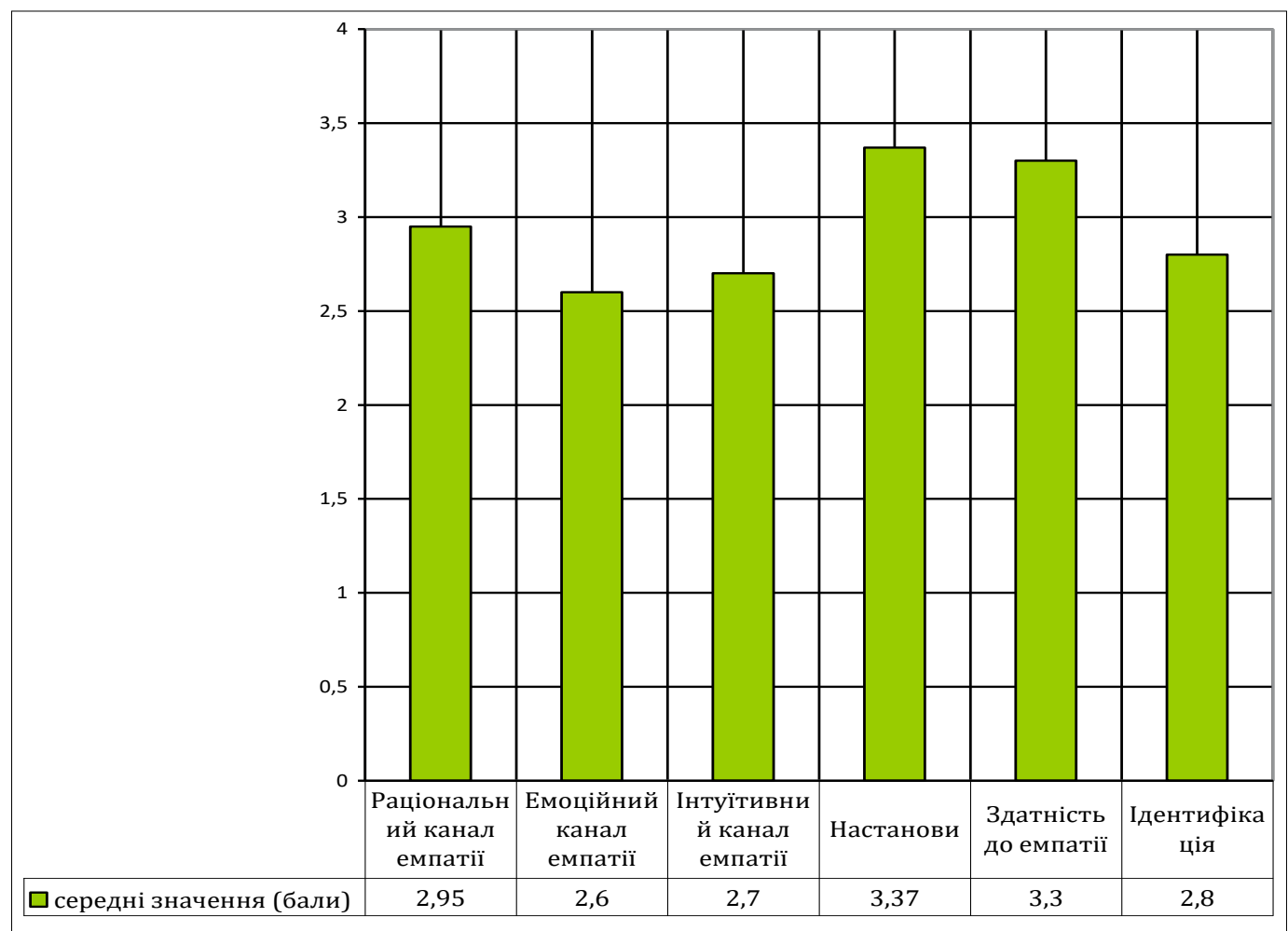

Рис. 2. Показники емпатійних здібностей у лікарів

ISSN 2663-970X insight.stateuniversity.ks.ua 
Thus, according to the above analysis, doctors are more focused on the essence of a person, his or her problem; they are inclined to see the state of other, tend to express interest and at the same time prefer an unstrained, sincere atmosphere in communication.

The maximum score on each scale is 6 points, so indicators above the average level (more than 3 points) include such scales as the mind attitudes and ability to the empathy. Scales with indicators below the average level include: identification and the emotional channel of empathy.

Results of the general level of empathy of doctors are of concern: $20 \%$ of the studied doctors have a very low level of empathy, half (50\%) is below the average level and 30\% had an average level. The studied doctors have not shown a high level of empathy. It should be noted that the empathy is seen by us as the ability to enter the state of another person, using imagination and intuition; empathy is a factor of a doctor's readiness to professional activity. Exactly the ability to put oneself in the place of another and respond emotionally to the patient's experiences facilitates the establishment of trusting relationships, which are necessary to build a therapeutic dialogue.

Consider results of the next aspect component of the emotional-and-motivational component of the mercy of doctors that is a development of the altruism. Results by the method of 0 . Potiomkina are presented in fig. 3 .

The obtained data have shown that the rates of orientation on both altruism (5.89 points) and egoism (4.3 points) are in the same numerical range of the average level. Such results may seem very contradictory firstly, as they appear to be two mutually exclusive tendencies, but this can be explained by the attempt to find a balance in the form of "appropriate" altruism, which does not imply sacrifice and emotional inclusion in all events.

The maximum number of points on each scale is 11 . Therefore, the highest rates have been obtained on the scale of orientation on the result (6.06 points), and the lowest has been got on the orientation on the egoism (4.3 points). Analyzing psychological profiles of the respondents, we can say that the studied doctors are aimed at obtaining the desired result and tend to act in favor of the result, even розуміється як входження до емоційного резонансу з іншим, глибоке співчуття та співучасть. Цей канал емпатії також пов'язаний iз певним енергетичним підстроюванням з метою розуміння внутрішнього світу та поведінки співрозмовника. Тож лікарі менше використовують емоційний канал емпатії: вони не налаштовані витрачати психічні сили для встановлення емоційного зв'язку або поглиблення до внутрішнього психологічного життя людини. Дещо вищі показники за шкалою інтуїтивного каналу емпатії (2.7 балів) свідчать про готовність досліджуваних спиратися, в першу чергу, на нелогічні та підсвідомі знання в оцінці поведінки та стану партнера.

Отже, згідно з приведеним аналізом, лікарі $\epsilon$ більш націленими на суть людини, їі проблему; вони налаштовані бачити стан іншого, схильні до виказування зацікавленості та водночас надають перевагу ненапруженій, щирій атмосфері у спілкуванні.

Максимальний бал за кожною шкалою 6.0 балів. Також до показників вище середнього рівня (більше 3-х балів) можна віднести такі шкали, як настанови та здатність до емпатії. До показників значно нижче середнього належать дані таких шкал, як ідентифікація та емоційний канал емпатії.

Занепокоєння викликають результати вивчення загального рівня емпатії лікарів: $20 \%$ досліджуваних лікарів мають дуже низький рівень емпатії, половина (50\%) - знижений рівень та $30.0 \%$ - середній рівень. Жоден 3 досліджуваних лікарів не продемонстрував високого рівня емпатії. Слід зауважити, що емпатія розглядається нами як здатність входити в стан іншої людини, застосовуючи уявлення та інтуїцію, становить собою фактор готовності лікаря до професійної діяльності. Саме здатність ставити себе на місце іншого та емоційно відгукуватися на переживання хворого сприяє встановленню довірчих стосунків, необхідних для побудови терапевтичного діалогу.

Розглянемо результати за наступною складовою емоційно-мотиваційного компоненту милосердя лікарів - розвиненістю альтруїзму. Результати за методикою О.Ф. Потьомкіної подані у рис. 3. 


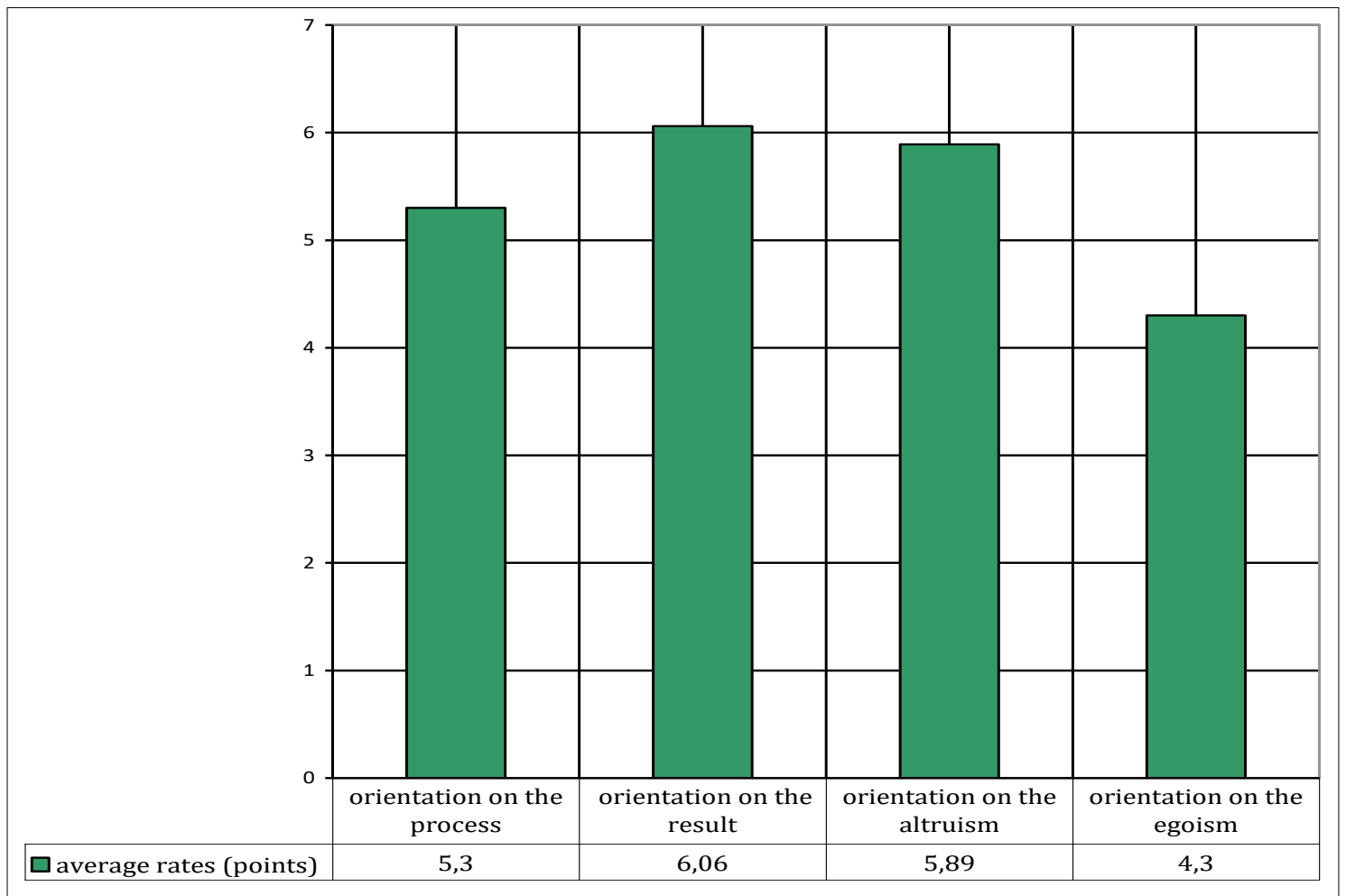

Fig. 3. Indicators of social and psychological attitudes in the motivational and needs sphere of doctors

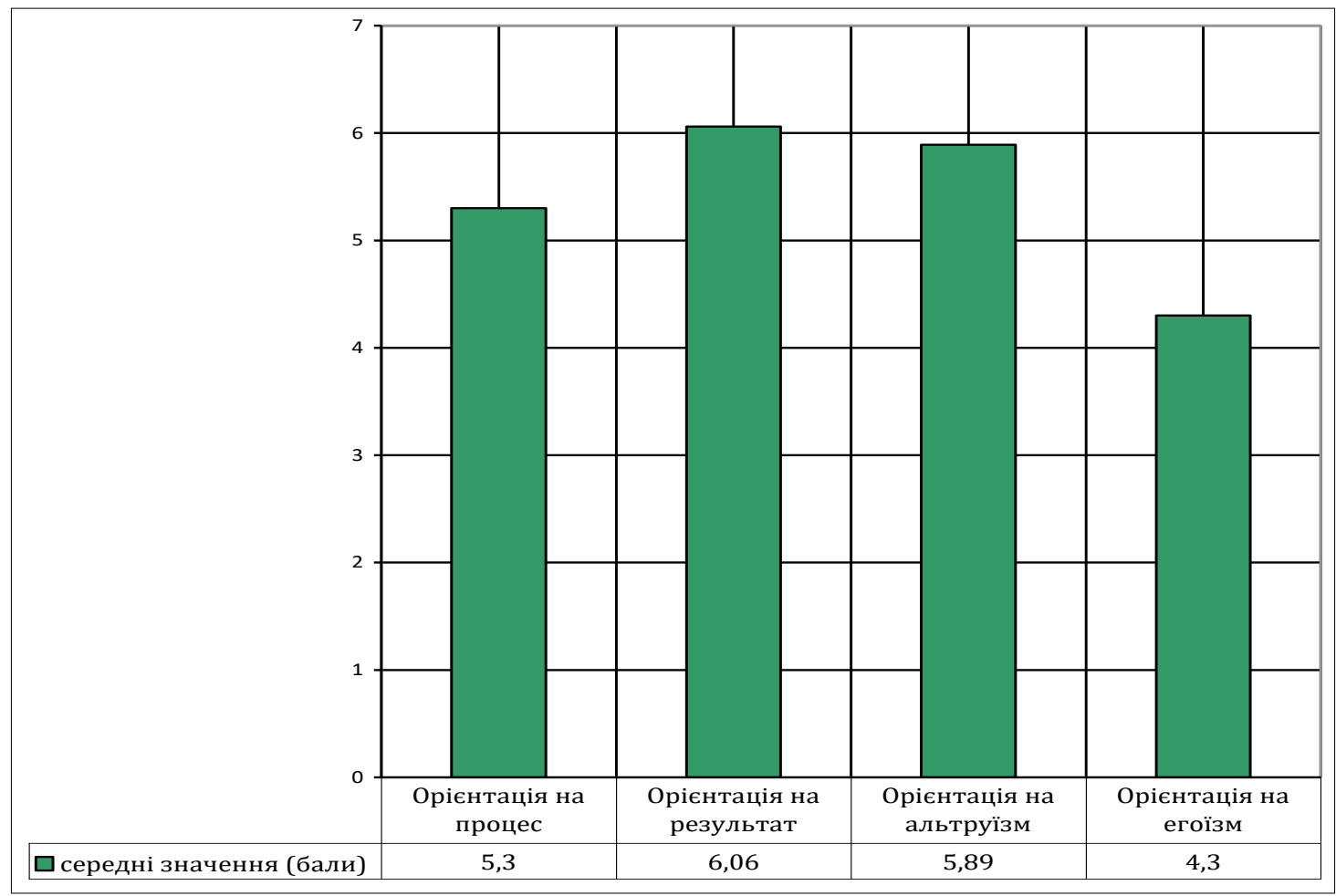

Рис. 3. Показники соціально-психологічних настанов особистості у мотиваційно-потребовій сфері лікарів 
in difficult conditions, in the presence of certain difficulties and failures.

According to the presented data, the studied doctors are less process-oriented (5.3 points). This means that they are more positive about the routine work required to achieve results, prone to methodical work, which may not even be interesting, but is necessary for ensuring future results.

Thus, the studied doctors do not have excessive egoism. Probably, when making important decisions, they tend to consider the consequences that affect them personally. Also, it is impossible to exclude the positive value of some part of the "reasonable egoism", the absence of which can harm a person.

Consider results of the study of the behavioral component of the mercy that is an implementation of the mercy behavior of doctors. The data obtained by the method of I. Yusupov are presented in Fig. 4.

A maximum score that can be obtained by a respondent on each of the scales is 15 points. Obviously, the sample does not show high results on any of the scales. Results that can be considered higher than the average level are in a group of doctors in such indicators as empathy towards parents (8.58 points), empathy in relation to the elderly ( 8.35 points) and empathy for strangers or unfamiliar people (8,1 points).

Interestingly, the lowest score has been recorded on the scale of empathy towards the children (6.02 points). In our opinion, this may be another proof of existence of a certain psychological protection, which requires doctors to distance themselves from the most emotionally influential situations, which maybe, for example, the treatment of a child.

Speaking of average scores of the general level of the empathy, which can be calculated from the sum of scores of all scales, the studied doctors got 44.2 points, which corresponds to the average level of empathy in behavior. The results show that the studied doctors are quite sensitive people, but are more likely to rely on their judgments about the actions of others than to trust their inner feelings and intuition. They control their emotional manifestations quite well and treat with caution to violent expression
Отримані дані засвідчили, що показники орієнтації як на альтруїзм (5,89 балів), так і егоїзм $(4,3$ балів) знаходяться в однаковому числовому діапазоні середнього рівня. Такі дані на перший погляд можуть бути дуже суперечливими, адже уявляється, що це дві взаємовиключні тенденції, проте це можна пояснити спробою знайти баланс у вигляді “доречного” альтруїзму, що не має на увазі жертовності та емоційного включення до всіх без винятку подій.

Максимальна кількість балів за кожною шкалою - 11.0. Тож найвищі значення досліджувані отримали за шкалою орієнтації на результат (6.06 балів), а найменші - 3 орієнтації на егоїзм (4.3 балів). Аналізуючи їх психологічний профіль, можна сказати, що досліджувані лікарі спрямовані на отримання бажаного результату та схильні діяти на користь результату навіть у складних умовах, при наявності певних труднощів та невдач.

Згідно з представленими даними, досліджувані медики $\epsilon$ менш орієнтованими на процес (5.3 балів) - тобто, більш позитивно ставляться до рутинної роботи, що необхідна для досягнення результатів, схильні до методичної праці, що може навіть не викликати цікавості, але $\epsilon$ необхідною для забезпечення результатів у майбутньому.

Отже, досліджувані лікарі не мають надмірно вираженого егоїзму. Ймовірно, при прийнятті важливих рішень вони схильні розглядати наслідки, що позначаються особисто на них. Також, нетреба виключати позитивне значення деякої частки "розумного егоїзму", відсутність якого може нашкодити людині.

Розглянемо результати дослідження за складовою поведінкового компонента милосердя - реалізацією милосердної поведінки у лікарів. Отримані дані за методикою I. М. Юсупова представлені на рис. 4.

Максимальним балом, що може отримати досліджуваний за кожною із шкал, є 15.0 балів. Очевидно, що вибірка не демонструє високі результати за жодною із шкал. Результати, які можна вважати вищими за середній рівень, має група лікарів за такими показниками, як емпатія по відношенню до батьків (8.58 балів), емпатія стосовно людей похилого віку (8.35 балів) та емпатія 

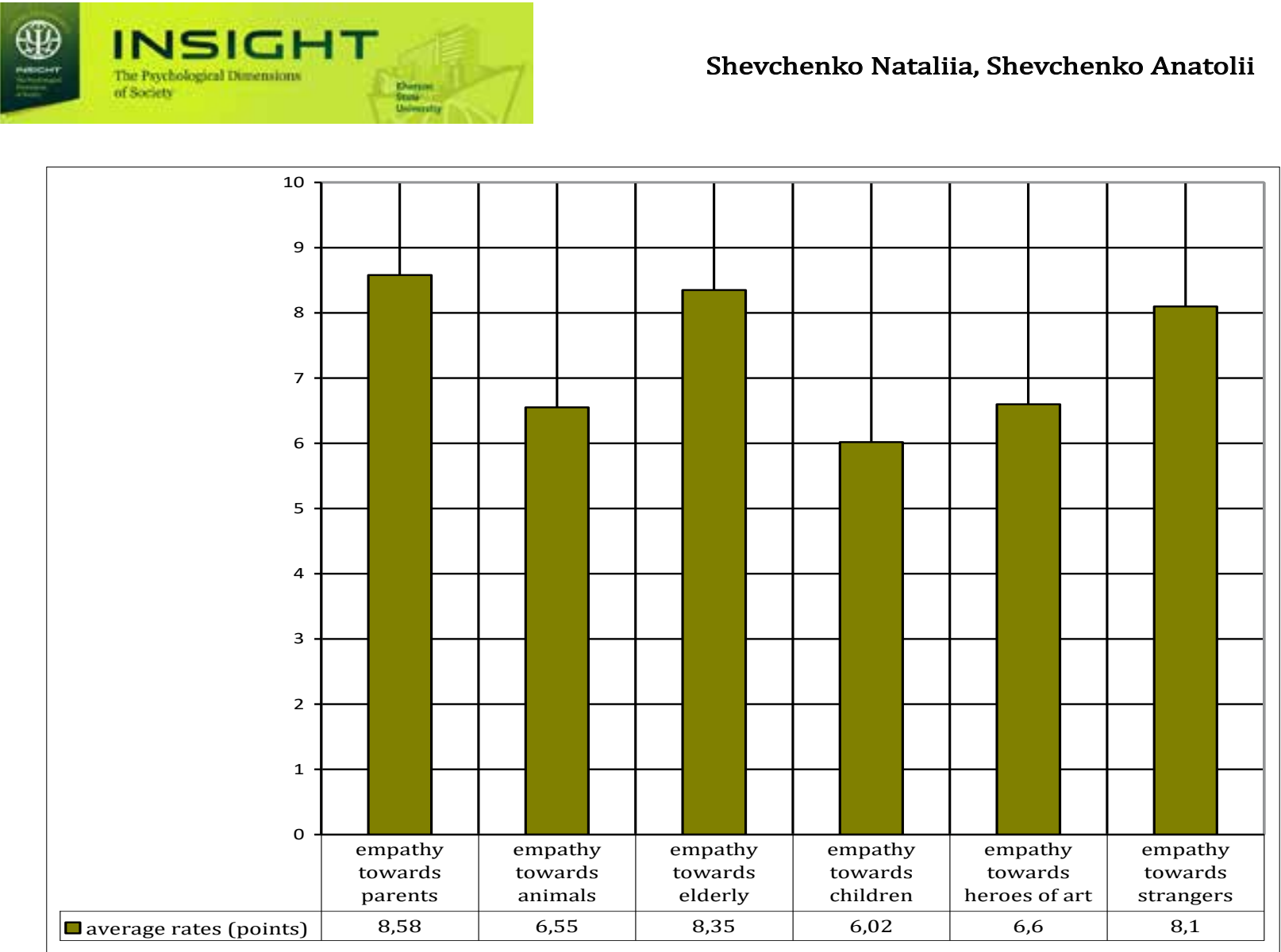

Fig. 4. Indicators of the empathic potential of doctors

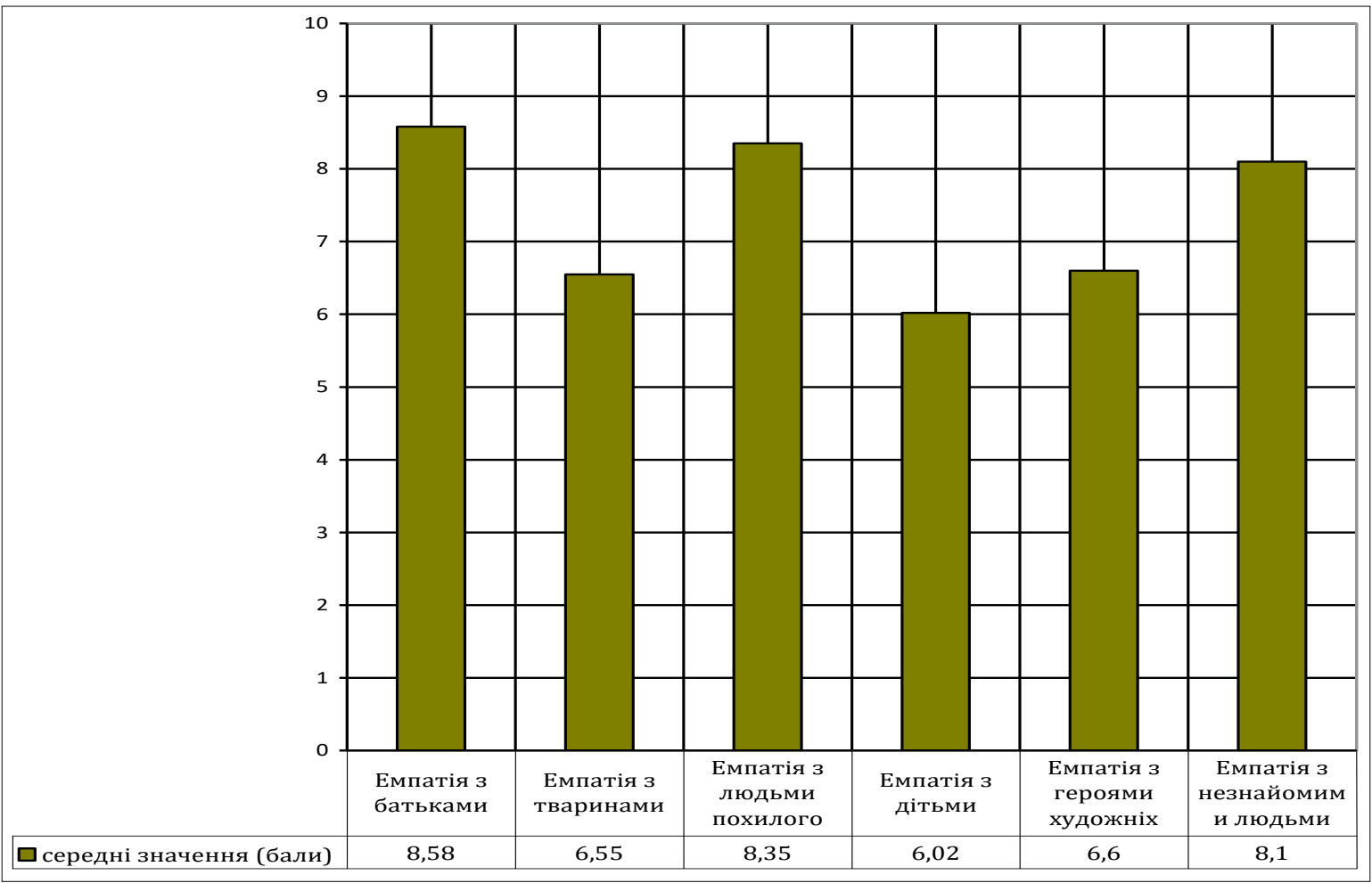

Pис. 4. Показники емпатійного потенціалу лікарів 
of emotions by another person. Sometimes other people's actions come as a surprise to them due to lack of imagination in predicting relationships.

In order to identify the general picture of correlation between the structural components of the mercy of doctors, we have used K. Pearson's method.

Correlation analysis has shown positive inter connections between all structural components of the mercy. Analysis of interconnections of the cognitive component with emotional-andmotivational and behavioral components has allowed to establish the following significant correlations:

- ability to empathy with the attitude to help $(\mathrm{r}=.30 ; \mathrm{p} \leq .01)$; notions of the mercy $(\mathrm{r}=.21$; $\mathrm{p} \leq .01)$; readiness for empathy $(\mathrm{r}=.42 ; \mathrm{p} \leq .01)$;

- orientation on altruism with attitude to help $(\mathrm{r}=.35 ; \mathrm{p} \leq .01)$; notions of the mercy $(\mathrm{r}=.29 ; \mathrm{p} \leq .01)$; readiness for empathy $(\mathrm{r}=.33$; $\mathrm{p} \leq .01)$;

- orientation on egoism with the notions of mercy $(\mathrm{r}=-.28$; $\mathrm{p} \leq .01)$; readiness for empathy $(\mathrm{r}=-.40 ; \mathrm{p} \leq .01)$. The revealed in versely proportional correlation means that the higher the orientation on egoism, the less this person thinks about the need for mercy and compassionate behavior;

- empathic potential with the attitude to help $(\mathrm{r}=.37$; $\mathrm{p} \leq .01)$; notions of the mercy $(\mathrm{r}=.27$; $\mathrm{p} \leq .01)$; readiness for empathy $(\mathrm{r}=.43 ; \mathrm{p} \leq .01)$.

Analysis of interconnections of the emotionaland-motivational component with the behavioral component has allowed to establish the following significant correlations:

- empathic potential with abilities to empathy $(\mathrm{r}=.32 ; \mathrm{p} \leq .01)$; orientation on altruism $(\mathrm{r}=.42$; $\mathrm{p} \leq .01)$; orientation on egoism $(\mathrm{r}=-.25 ; \mathrm{p} \leq .01)$.

Thus, results of the correlation analysis have shown the existence of positive interconnections between all structural components of the mercy. The revealed strength of correlations confirms the assumption that mercy as a professionally important quality of a doctor is determined by the harmonious development of cognitive, emotional-and-motivational and behavioral components. Results of the study also confirm that under usual conditions of professional activity, mercy is not manifested enough. відносно незнайомих або малознайомих людей (8.1 балів).

Цікаво, що найнижчий результат зафіксовано за шкалою емпатії з дітьми (6.02 балів). На нашу думку, це може бути ще одним доказом існування певного психологічного захисту, що вимагає медиків відсторонюватися від найбільш емоційно впливових ситуацій, якою може бути, наприклад, лікування дитини.

Говорячи про середні показники загального рівня емпатії, що можна підрахувати за сумою показників всіх шкал, досліджувані лікарі мають 44.2 балів, що відповідає середньому рівню прояву емпатії у поведінці. Отримані результати свідчать про те, що досліджувані лікарі - досить чутливі особи, але більш схильні покладатися на свої судження щодо вчинків інших людей, ніж довіряти внутрішнім відчуттям та інтуїції. Досить добре контролюють свої емоційні прояви та з обережністю ставляться до бурхливого виказування емоцій з боку іншої людини. Іноді вчинки інших людей стають для них несподіванкою - через брак уяви у прогнозуванні стосунків.

3 метою виявлення загальної картини взаємозв'язку структурних компонентів милосердя у лікарів було проведено кореляційний аналіз за допомогою коефіцієнту кореляції за К. Пірсоном (r).

За результатами кореляційного аналізу було зафіксовано наявність позитивних взаємозв'язків між всіма структурними компонентами милосердя. Аналіз взаємозв'язку когнітивного компоненту з емоційно-мотиваційним та поведінковим компонентами дозволив встановити наступні значущі взаємозв'язки:

- розвиненості емпатійних здібностей 3 ставленням до допомоги $(\mathrm{r}=0.30 ; \mathrm{p} \leq 0.01)$; уявленням про милосердя $(\mathrm{r}=0.21 ; \mathrm{p} \leq 0.01)$; готовністю до емпатії (r=0.42; $\leq \leq 0.01)$;

- орієнтації на альтруїзм 3 ставленням до допомоги $(\mathrm{r}=0.35 ; \mathrm{p} \leq 0.01) ;$ уявленням про милосердя $(\mathrm{r}=0.29 ; \mathrm{p} \leq 0.01) ;$ готовністю до емпатії $(\mathrm{r}=0.33 ; \mathrm{p} \leq 0.01)$;

- орієнтації на егоїзм з уявленням про милосердя $(\mathrm{r}=-0.28 ; \mathrm{p} \leq 0.01) ;$ готовністю до емпатії $(\mathrm{r}=-0.40 ; \mathrm{p} \leq 0.01)$. Виявлена обернено пропорційна кореляція означає, що чим вищою $є$ егоїстична орієнтація, тим менше 


\section{Discussion}

The obtained results are in agreement with the data of our previous research (Shevchenko \& Markova, 2019), which conducted a comparative analysis of development of doctors' mercy and specialists of other professions. Statistically proved the presence of certain differences in the mercy manifestation in both groups on the following indicators: empathy channel (emotional for non-medical professions; rational for doctors), social and psychological attitudes of a personality (orientation on the process for non-medical professions; orientation on the result for doctors); instrumental values (more important values among the medicians are accuracy, education); attitude to help (doctors have more positive attitude to providing and receiving care).

At the same time, speaking about the qualitative characteristics of the mercy manifestation of doctors, it should be noted that most of the studied parameters have been recorded in the range of the average level. Consider the obtained results by the mercy components particularly.

Cognitive component. Respondents can be characterized by a positive attitude to help and positive notions of the mercy, while their notions of empathy are lower. Speaking of the mercy, respondents tend to use positive and warm words. Results of the empathy research can be explained by the presence of sharply negative responses to situations that describe the emotional inclusion and concerning of the condition of other people. From our point of view, this clarifies peculiarity of the empathy as something that requires limiting choice of the empathy objects and preventing emotional burnout of doctors. Thus, it can be assumed that a doctor must allocate his or her emotional forces according to the arising situation. In our opinion, such understanding and management of own resources should be considered as one of the characteristics of a doctor's professional competence. Naturally, the question arises whether the empathy can be considered as an existential resource, or whether the empathy itself requires other resources - social, psychological, and so on.

Emotional-and-motivational component. Research of specifics of the empathic abilities особа замислюється над необхідністю милосердя та милосердної поведінки;

- емпатійного потенціалу зі ставленням до допомоги $(\mathrm{r}=0.37 ; \mathrm{p} \leq 0.01) ;$ уявленням про милосердя $(\mathrm{r}=0.27 ; \mathrm{p} \leq 0.01) ;$ готовністю до емпатії $(\mathrm{r}=0.43 ; \mathrm{p} \leq 0.01)$.

За результатами кореляційного аналізу було зафіксовано наявність позитивних взаємозв'язків між всіма структурними компонентами милосердя. Аналіз взаємозв'язку емоційно-мотиваційного та поведінкового компонентів милосердя дозволив встановити такі значущі взаємозв'язки:

- емпатійного потенціалу з емпатійними здібностями ( $\mathrm{r}=0.32 ; \mathrm{p} \leq 0.01)$; орієнтацією на альтруїзм ( $\mathrm{r}=0.42 ; \mathrm{p} \leq 0.01)$; орієнтацією на егоїзм $(\mathrm{r}=-0.25 ; \mathrm{p} \leq 0.01)$.

Отже, результати кореляційного аналізу засвідчили наявність позитивних взаємозв'язків між всіма структурними компонентами милосердя. Виявлена міцність кореляційних зв'язків підтверджує припущення про те, що милосердя як професійно-важлива якість лікаря, визначається гармонійним розвитком когнітивного, емоційно-мотиваційного та поведінкового компонентів.

\section{Дискусія}

Отримані результати суголосні 3 даними нашого попереднього дослідження (Shevchenko, Markova, 2019), у якому було проведено порівняльний аналіз розвитку милосердя у лікарів та у працівників інших професій. Статистично доведено наявність певних відмінностей у прояві милосердя у представників обох груп за такими показниками: канал емпатії (емоційний - у представників немедичних професій; раціональний - у медиків), соціально-психологічні настанови особистості (орієнтація на процес - у представників немедичних професій; орієнтація на результат у медиків); інструментальні цінності (більше значення цінностей акуратність, освіченість для медиків); ставлення до допомоги (більша позитивна налаштованість на надання та отримання допомоги - у лікарів).

Водночас, говорячи про якісні характеристики прояву милосердя у лікарів, слід відзначити, що більшість досліджуваних параметрів 
of doctors has shown that none of the respondents has a high level of the empathy. That is, most of the studied doctors are not inclined to establish emotional connections and empathy, even in the form of "I am with you" as the ability to enter the world of another person while maintaining the ability to return to the real world at any time. This may be due to the inability to regulate own emotional state, understand own emotions, and set boundaries. On the other hand, there is a question about the role of the empathy level of a doctor in view of the professional burnout but consideration of this problem is not one of the main goals of our study. It can be assumed that, according to the analysed theoretical views, the empathy decrease may play the role of a certain psychological protection.

These results are also similar to the data of other scientists: in comparison with the results of the study by S. Mitina (Mitina, 2017), where $80 \%$ of doctors had low and below average levels of empathy. In our research, this rate is at the level of $70 \%$, but the percentage of doctors with an average level of empathy is significantly higher (30\% vs. $18 \%$ ). The average rate of the empathy is at the level of 17.43 points, which, although included in the range of low levels of the empathy, is higher than in the study of O. Grogoleva (16.01 points) (Grogoleva, 2007).

It is difficult to compare the results with the data of T. Nedovodieeva's study (Nedovodieeva, 2006), because our respondents are not medical students who are only at the stage of formation of professional self-consciousness but already working professionals with different indicators of work experience. So, they have already overcome the first difficulties associated with encountering pictures of human pain and suffering and remained in the chosen profession.

Behavioral component. Implementation of the mercy behavior of doctors corresponds to an average level. It has been unexpected the lack of the highest level of empathy towards strangers and unfamiliar people because this category is the main in doctors' professional interaction. We can assume that the identified specificity of manifestation of the empathy of doctors is associated with a certain psychological protection; also, a possible appropriate solution зафіксовано в діапазоні середнього рівня. Розглянемо детальніше отримані результати за компонентами милосердя.

Когнітивний компонент. Для респондентів характерним $\epsilon$ позитивне сприйняття допомоги та позитивне уявлення про милосердя, водночас уявлення про емпатію виявилися нижчими. Говорячи про милосердя, досліджувані схильні використовувати позитивні та теплі слова. Результати досліджуваних щодо емпатії можна пояснити наявністю різко негативних відповідей на ситуації, що описували емоційне включення та переймання станом всіх інших людей. 3 нашої точки зору, це прояснює особливість емпатії як того, що вимагає все ж таки обмежувати вибір об'єктів емпатії та запобігати емоційному вигорянню лікаря. Таким чином можна припустити, що лікар повинен розподіляти свої емоційні сили відповідно до ситуації, що виникає. На нашу думку, таке розуміння своїх ресурсів та управління ними має розглядатися як одна з характеристик професійної компетентності лікаря. Закономірно постає питання про те, чи можна розглядати емпатію як екзистенційний ресурс, чи виявлення емпатії само по собі потребує наявності інших ресурсів соціальних, психологічних тощо.

Емоційно-мотиваційний компонент. Вивчення специфіки емпатійних здібностей лікарів показало, що жоден респондент не продемонстрував високого рівня емпатії. Тобто опитані нами лікарі у свойй більшості не схильні до встановлення емоційного зв'язку та співпереживання навіть у формі “я з Вами" як здатність увійти до світу іншого, одночасно зберігаючи можливість у будьякий момент повернутися до реального світу. Можливо це є наслідком невміння регулювати власний емоційний стан, розуміння своїх емоцій та встановлення кордонів. 3 іншого боку, постає питання щодо ролі рівня емпатії лікаря 3 огляду на його професійне вигорання - але розгляд цієї проблеми не $є$ однією з основних цілей нашого дослідження. Можна припустити, що, згідно з розглянутими теоретичними поглядами, зниження емпатії може виконувати роль певного психологічного захисту.

Ці результати також є подібними до тих, що були розглянуті нами у теоретичній частині, а саме: у порівнянні з результатами 
may be distinguishing the concept of the "clinical mercy" such as the "clinical empathy" (Gelhaus, 2012), which will have certain structural features. Perhaps such data may be caused by the peculiarity of a doctor's work: on the one hand, under conditions of stress, lack of time and contemplation of human suffering, simplicity of setting the emotional connection is lost; on the other hand, there may be no need for emotional understanding due to the presence of rich life experience. Thus, having acquired certain skills in understanding people intellectually, a doctor will not need emotional "adjusting" to each patient and thus retain a remarkable psychological resource.

\section{Conclusions}

Thearticlehashighlightedresultsofanempirical research of features of the mercy manifestation of doctors. A structural model of doctors' mercy has been presented, which includes cognitive, emotional-and-motivational and behavioral components. Study of the cognitive component manifestation has shown that the respondents' attitude to the key parameters is mainly positive. The doctors can be characterized by a positive attitude to help (in relation to both help assisted and recipient of help) and a positive perception of the mercy, while notions of the empathy have lower scores. Study of the empathic abilities (emotional-and-motivational component) has shown that the doctors tend to rely on a rational channel of empathy, have well-developed guidelines for empathy and prefer to create a trusting atmosphere. Most of the respondents are not inclined to establish emotional connections and empathy as the ability to enter the world of another person while maintaining the ability to return to the real world at any time. Research of personal social and psychological attitudes in the motivational and needs sphere (emotionaland-motivational component) have recorded an average level of altruistic orientations. The studied doctors are aimed at obtaining the desired result and tend to act in favor of the result, even in difficult conditions, in the presence of certain difficulties and failures. Study of manifestation of the behavioral component of mercy has indicated that the doctors mainly show empathy дослідження С. В. Мітіної (Мітіна, 2017), де 80.0\% лікарів мали низький та нижчий за середній рівень емпатії. В нас цей показник знаходиться на рівні $70.0 \%$, але відсоток лікарів, що мають середній рівень емпатії є суттєво вищим (30.0\% проти 18.0\%). Середній показник емпатії знаходиться на рівні 17,43 балів, що, хоча і входить до інтервалу низького рівня емпатії, $\epsilon$ вищім, ніж у дослідженні О. Ю. Гроголевої (16,01 балів) (Гроголева, 2007).

Важко порівнювати результати 3 даними дослідження Т. О. Недоводєєвої (Недоводеева, 2006), бо нашими досліджуваними є не студенти-медики, що знаходяться лише на стадії формування професійної самосвідомості, а вже працюючі професіонали з різними показниками трудового досвіду. Отже, вони вже подолали перші труднощі, пов'язані із зіткненням 3 картинами людського болю та страждань, та залишилися в обраній професії.

Поведінковий компонент. Реалізація милосердної поведінки в лікарів відповідає середньому рівню. Несподіваною була відсутність у групі лікарів вищого рівня емпатії по відношенню до малознайомих та незнайомих людей - бо ця категорія $€$ основною у професійній взаємодії. Ми можемо припустити, що виявлена специфіка прояву емпатії лікарів пов'язана з певним психологічним захистом; також можливим доцільним виходом може бути виокремлення поняття “клінічного милосердя" на зразок “клінічної емпатії” (Gelhaus, 2012), що матиме певні структурні особливості. Можливо, такі дані обумовлені також особливістю роботи лікаря: адже, з одного боку, за умов стресу, браку часу та споглядання людських страждань втрачається легкість встановлення емоційного зв'язку; з іншого боку, може відпадати необхідність в емоційному розумінні через наявність багатого життєвого досвіду. Отже, набувши певних навичок у розумінні людей інтелектуальним шляхом, лікар не матиме необхідності "налаштовуватися" емоційно на кожного пацієнта та зберігатиме таким чином неабиякий психологічний ресурс.

\section{Висновки}

В статті представлено результати емпіричного дослідження особливостей прояву

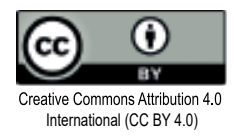


towards parents, towards the elderly and towards strangers or unfamiliar people. The average level of empathy in behavior has been stated: the respondents are quite sensitive people, but are more likely to rely on their judgments about the actions of others than to trust their inner feelings and intuition.

Results of the correlation analysis have shown the existence of positive inter connections between all structural components of the mercy. The revealed strength of correlations has confirmed the assumption that mercy as a professionally important quality of a doctor is determined by the harmonious development of cognitive, emotional-and-motivational and behavioral components.

Originality of the empirical study lies in revelation of the mercy structural organization of doctors, as well as in the practical significance of the obtained theoretical and empirical materials. Results of the study can be used in creation of training programs for future medicians, as well as for elaboration of programs of educational influences and guidelines for practical and medical psychologists. A package of psychodiagnostic techniques for study of the mercy can be used in further studies of this phenomenon.

Promising directions of further research concern elaboration and approbation of the psychological support program to increase the level of mercy of doctors.

\section{References}

Borysiuk, A. S. (2019). Research of the peculiarities of motivation sphere of future doctors. Insight: the psychological dimensions of society, 1, 102-109.

Danyuk, M. I. (2016). Formation of professionally significant qualities of future junior specialists in nursing in the process of professional training. Candidate's thesis. Ternopil.

Gelhaus, P. (2012). The desired moral attitude of the physician: (I) empathy. Med. Health. Care Philos., 15(2), 103-113.

Gilbert, P. (2019). The Compassionate Mind. Compassion Focused Therapy. Robinson; Re-issue edition.

Grogoleva, O. Yu. (2007). Features of the patient's image among different categories of medical workers, depending on the level of empathy. Omsk University Bulletin. Series "Psychology", 11-16.

Halian, A., Halian, I., Burlakova, I., Shevchenko, R., Lappo, V., Zhigarenko, I. \& Popovych, I. (2020). Emotional Intelligence in the Structure of Adaptation милосердя у лікарів. Представлено структурну модель милосердя лікарів, яка включає когнітивний, емоційно-мотиваційний та поведінковий компоненти. Вивчення прояву когнітивного компонента милосердя у лікарів показало, що досліджувані помірно позитивно ставляться до ключових параметрів. Для лікарів характерним $€$ позитивне сприйняття допомоги (у відношенні як до об'єкта, що отримує допомогу, так і до суб'єкта, що сприймає ії) та позитивне уявлення про милосердя, водночас уявлення про емпатію виявилися нижчими. Вивчення емпатійних здібностей (емоційно-мотиваційний компонент) у лікарів засвідчило, що лікарі схильні спиратися на раціональний канал емпатії, мають розвинені настанови на емпатію та надають перевагу створенню довірливої атмосфери. Більшість респондентів не схильні до встановлення емоційного зв'язку та співпереживання як здатності увійти до світу іншого, одночасно зберігаючи можливість у будь-який момент повернутися до реального світу. Дослідження соціально-психологічних настанов особистості у мотиваційно-потребовій сфері (емоційно-мотиваційний компонент) зафіксували середній рівень прояву альтруїстичних настанов. Лікарі спрямовані на отримання бажаного результату та схильні діяти на користь результату навіть у складних умовах, при наявності певних складнощів та невдач. Вивчення прояву поведінкового компонента милосердя показало, що для лікарів найбільш характерно проявляти емпатію по відношенню до батьків, по відношенню до людей похилого віку та по відношенню до незнайомих або малознайомих людей. Констатовано середній рівень прояву емпатії у поведінці: досліджувані - досить чутливі особи, але більш схильні покладатися на свої судження щодо вчинків інших людей, ніж довіряти внутрішнім відчуттям та інтуїції.

За результатами кореляційного аналізу було зафіксовано наявність позитивних взаємозв'язків між всіма структурними компонентами милосердя. Виявлена міцність кореляційних зв'язків підтверджує припущення про те, що милосердя як інтегральна особистісно і професійно значуща якість лікаря, визначається гармонійним розвитком когнітивного, емоційно-мотиваційного та поведінкового компонентів.

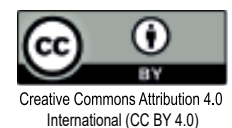

insight.stateuniversity.ks.ua ISSN 2663-970X 
Process of Future Healthcare Professionals. Revista Inclusiones, 7(3), 447-460.

Koval, O. E. (2017). The act of charity as a canon of moral formation of personality. Science and education: scientific-practical magazine, 1, 42-48.

Luskin, F. (2010). Forgive for good: a proven prescription for health and happiness. Harper One; Reprintedition.

Matiukha, L. F, Medvedovska, N. V., Bukhanovska, T. M., Dikhtiarenko, I. Yu. (2020). Sociological study results of self-assessment possibilities for self-realization among doctors of general practice - family medicine in Ukraine. Wiadomości Lekarskie, LXXIII (3), 454-456.

Mitina, S. V. (2017). Empathy as a professionally important quality of a medical worker. Scientific Bulletin of Kherson State University. 1(1), 83-88.

Nedovodieeva, T. A. (2006). Upbringing of future nurses' mercy. Candidate's thesis. Kostroma.

Neff, K. D. \& Germer, C. (2017). Self-Compassion and Psychological Wellbeing. In J. Doty (Ed.) Oxford Handbook of Compassion Science, Chap. 27. Oxford University Press.

Shevchenko, N., \& Markova, M. (2019). Comparative analysis of peculiarities of mercy manifestations in medical staff and representatives of other socionomic professions. Psychiatry, psychotherapy and clinical psychology: International scientific and practical journal, 10 (2), 353-362.

Solodukho, V. V. (2014). Social intelligence and emotional burnout in health professionals. Psychiatry, psychotherapy and clinical psychology: International scientific and practical journal, 4, 63-71.

Ushakova, K. Yu. (2018). Psychological factors of the formation of professional "Self-concept" among students of medical colleges. Candidate's thesis. Kiev.

Yudina, O. M. (2004). Psychological features of empathy formation of future doctors. Extended abstract of Candidate's thesis. Kyiv.

Yuriyeva, L. (2019). Educational programs for burnout prevention among healthcare professionals in the field of mental health. Psychiatry, psychotherapy and clinical psychology: International scientific and practical journal, 10 (2), 345-352.
Оригінальність емпіричного дослідження полягає у розкритті структурної організації милосердя в лікарів, а також у практичній значущості отриманих теоретичних та емпіричних матеріалах. Результати дослідження можуть використовуватися при створенні навчальних програм майбутніх лікарів, а також для розробки програм виховних впливів і методичних рекомендацій для практичних та медичних психологів. Пакет психодіагностичних методик для вивчення милосердя може бути використаний у подальших дослідженнях цього феномену.

Перспективним напрямом розвитку наукової проблематики вважаємо розробку та апробацію програми психологічного супроводу з підвищення рівня прояву милосердя у лікарів.

\section{Список використаних джерел}

Borysiuk A. S. Research of the peculiarities of motivation sphere of future doctors. Insight: the psychological dimensions of society, 2019. Vol. 1. P. 102-109.

Данюк М. I. Формування професійно значущих якостей майбутніх молодших спеціалістів сестринської справи в процесі фахової підготовки: дис. ... канд. пед. наук; Тернопіль, 2016. 309 c.

Gelhaus P. The desired moral attitude of the physician: (I) empathy. Med. Health. Care Philos. 2012. № 15(2). P. 103-113.

Gilbert P. The Compassionate Mind. Compassion Focused Therapy. Robinson; Re-issue edition, 2019. 624 p.

Гроголева О.Ю. Особенности образа больного у различных категорий медицинских работников в зависимости от уровня эмпатии. Вестник Омского университета. Серия “Психология", 2007, 2. С. 11-16.

Halian A., Halian I., Burlakova I., Shevchenko R., Lappo V., Zhigarenko I., Popovych I. Emotional Intelligence in the Structure of Adaptation Process of Future Healthcare Professionals. Revista Inclusiones. 2020. Vol. 7, No 3. P. 447-460.

Коваль 0. Є. Вчинок милосердя як канон морального становлення особистості. Наука і освіта : наук.практ. журнал. 2017. № 1. С. 42-48.

Luskin F. Forgive for good: a proven prescription for health and happiness. Harper One; Reprint edition, 2010. 244 p.

Matiukha L. F., Nataliia V., Medvedovska N. V., Bukhanovska, T. M., Dikhtiarenko, I. Yu. Sociological study results of self-assessment possibilities for 
self-realization among doctors of general practice family medicine in Ukraine. Wiadomości Lekarskie. 2020. Vol. LXXIII, No 3. P. 454-456.

Мітіна С. В. Емпатія як професійно важлива якість медичного працівника. Науковий вісник Херсонського державного університету. Вип. 1. T. 1. 2017. C. 83-88.

Neff K. D., Germer C. Self-Compassion and Psychological Wellbeing. In J. Doty (Ed.) Oxford Handbook of Compassion Science, Chap. 27. Oxford University Press, 2017.

Недоводеева Т. А. Воспитание милосердия у будущей медицинской сестры: дис. канд. пед. наук. Кострома, 2006. 253 с.

Shevchenko N., Markova M. Comparative analysis of peculiarities of mercy manifestations in medical staff and representatives of other socionomic professions. Психиатрия, психотерапия и клиническая психология: Международный научно-практический журнал, 2019. Том 10, № 2. C. 353-362.

Солодухо В. В. Социальный интеллект и эмоциональное выгорание у медицинских работников. Психиатрия, психотерапия и клиническая психология: Международный научнопрактический журнал. 2014. № 4. С.63-71.

Ушакова К. Ю. Психологічні чинники становлення професійної “Я-концепції” у студентів медичних коледжів : автореф. дис. ... канд. психол. наук. Київ, 2018. 20 с.

Юдіна О. М. Психологічні особливості формування емпатійності майбутніх лікарів : автореф. дис. ... канд. психол. наук. К., 2004. 20 с.

Yuriyeva L. (2019). Educational programs for burnout prevention among healthcare professionals in the field of mental health. Психиатрия, психотерапия и клиническая психология: Международный научно-практический журнал. 2019. Том 10, № 2, С. 345-352. 